\title{
In-vitro Evaluation of Bio-control agents against Soil Borne Plant Pathogens
}

\author{
Shrinkhala Manandhar ${ }^{1 @}$, Bimala Pant ${ }^{1}$, Chetana Manandhar ${ }^{1}$ and Suraj Baidya ${ }^{2}$ \\ ${ }^{1}$ Plant Pathology Division, Nepal Agricultural Research Council, ${ }^{2}$ Plant Pathology Division, Nepal Agricultural \\ Research Council, Nepal @: shrinkhala25@gmail.com; ORCID: https://orcid.org/0000-0002-9997-8900; \\ BP: binu_pant2000@yahoo.com; CM: chetana.manandhar@gmail..com; SB:suraj_baidya222@yahoo.co.in
}

Received 29 March 2018, Revised 17 Sept 2018, Accepted 25 Dec 2018, Published 28 April 2019

Scientific Editors: Subash Subedi, Sarswati Neupane, Neena Amatya Gorkhali

Copyright (C) 2019 NARC. Permits unrestricted use, distribution and

reproduction in any medium provided the original work is properly cited.

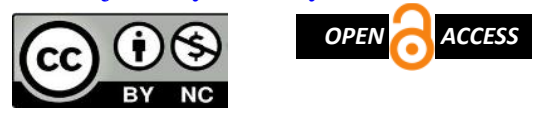

Licensed under the Creative Commons AttributionNonCommercial 4.0 International (CC BY-NC 4.0)

\begin{abstract}
Biocontrol is an important aspect of disease management for plant pathogens, especially for the soil borne fungi. Trichoderma species is the most exploited biocontrol agent in recent years. The soil specific nature of Trichoderma species is a well-known fact and hence native Trichoderma isolates should be more emphasized for control of plant pathogens. Fifty soil samples from rhizosphere of various agricultural crops were collected for isolation of Trichoderma sp. Ten isolates of Trichoderma were tested in dual culture with soil borne pathogens Fusarium solani, Rhizoctonia solani and Sclerotinia sclerotiorum in an in vitro assay. All of the test isolates were found to be significant in terms of mycelial inhibition growth as compared to control. However, varying degrees of antagonism by different Trichoderma isolates were observed for above mentioned soil borne pathogens. The isolate (T363) was found to exhibit more than $80 \%$ inhibition of S. sclerotiorum while the isolate T357 was found to control F. solani by more than $80 \%$. For the control of $R$. solani, six of the tested Trichoderma isolates showed more than $80 \%$ inhibition of its radial colony growth. The Trichoderma isolates seen effective in this study need to be tested in pot and field experiments for exploiting the use and benefits of biocontrol.
\end{abstract}

Keywords: Biocontrol, Rhizosphere, Soil borne pathogens, Trichoderma

सारांश

रासायनिक बिषादीको अत्याधिक प्रयोगले मानव लगाएत अन्य विभिन्न क्षेत्रहरुमा देखापर्ने समस्या वारे चेतना बढ़दै जाँदा बाली रोग ब्यबस्थापनको लागि जैविक नियन्त्रणको प्रयोगले अहिले धेरै महत्व बोकेको छ। ट्राइकोडर्मा हाल जैविक नियन्त्रणका लािि सबैभन्दा बढ़ी प्रयोगमा आएको फाइदाजनक ढुसी हा। ट्राइकोडर्माका विभिन्न प्रजातिहरू हुन्छन् र ती सबै एकै प्रकारको माटो वा बातावरणमा बाँच्न र फस्टाउन सक्दैनन् । त्यस कारण बाहिरबाट आयातित ट्राइकोडर्मा भएका जैविक बिषादी नेपालको परिपेक्षमा प्रभावकारी नहुन सक्छन् । नेपालकै रैथाने र यहीं माटोमा भएको ट्राइकोडर्मा प्रयोगशालामा हेरी प्रभावकारी प्रजाति छान्ने उद्देश्यले यो परिक्षण गरिएको थियो । विभिन्न ठाउंहरुबाट माटोका नमुना संकलन गरी माटोबाट ट्राइकोडर्मा निकालियो र जम्मा 90 वटा ट्राइकोडर्माका प्रजातिहरु लाई तीन विभिन्न माटोजनित रोगको जीवाणुहरुसंग जैविक ढुसि र रोग कारक ढुसि एकैसाथ वृद्धि गर्ने प्रविधि (ड्यूल कल्चर टेक्निक) बाट परिक्षण गरियो । ट्राइकोडर्मा को प्रजाति $\mathrm{T}$ ३६३ ले $५ ० \%$ भन्दा बढ़ले स्क्लेरोटिनिया ढुसीको वृद्धि रोक्यो भने अर्को प्रजाति $\mathrm{T}$ ३乡७ ले पनि ५०\% ले फ्युजारियम ढुसीको वृद्धिलाइ रोक्न सफल भयो । त्यस्तै राइजोक्टोनिया ढुसी नियन्त्रणका लागि ६ वटा ट्राइकोडर्मा प्रजातिहरु प्रभावकारी देखिए । प्रयोगशालामा राम्रो पाइएका यी ट्राइकोडर्माका प्रजातिहरुलाई गमला तथा खेतवारीमा परिक्षण गरी जैविक नियन्त्रणको उपयोगिता र प्रयोगमा व्यापकता जरुरी छ।

\section{INTRODUCTION}

Plant pathogens are major constraints for increased crop yields. Among the pathogens, soil borne plant pathogens viz Fusarium solani, Rhizoctonia solani and Sclerotinia sclerotiorum are ubiquitous in nature and have wide host range. Biological control of soil borne pathogens is an environmentally sound method and avoids other threats posed by the use of chemicals such as health hazards and development of resistance 
in pathogens (Kumar et al 2017). The antagonistic activity of Trichoderma was demonstrated more than eight decades ago (Weindling 1934) and today it is the most extensively used biocontrol agent (Mukherjee et al 2012). Trichoderma are free living microorganisms which are abundant in nature and can be isolated from soil, plant roots, decaying wood or other organic matter (Motlagh et al 2013). More than 100 species of Trichoderma have been recorded worldwide (Pandya et al 2011), many of which are potential biocontrol agents (Benitez et al 2004). Trichoderma are mainly used for the control of soil borne pathogens as these biocontrol agents inhabit soil (Ha 2010). Many commercial biopesticides with Trichoderma sp as are available in developed countries (Junaid et al 2013, Kumar et al 2017). However, it should be clearly understood that not all Trichoderma are effective in controlling pathogens and therefore it is essential to find out the Trichoderma with biocontrol potential which is possible through in vitro tests subsequently followed by pot and field experiments. Native Trichoderma can have significant biocontrol potential as they are adapted to the environment while exotic Trichoderma introduced to a new ecological niche can have problems of climatic adaptability and colonization in soils (Kamala and Devi 2012, Ommati and Zaker 2012). Therefore, this study was carried out to identify native Trichoderma isolates with biocontrol potential against the very common soil borne plant pathogens.

\section{MATERIALS AND METHODS}

\section{Isolation of Trichoderma Isolates}

Soils were collected from rhizosphere of various agricultural crops from different locations in the year of 2017 and plated on PDA media. Serial dilutions were followed for the isolation of Trichoderma from 50 soil samples. For each soil sample, three dilutions of $10^{1}, 10^{2}$ and $10^{3}$ were followed. Plates were incubated at $25^{\circ} \mathrm{C}$ until observation of Trichoderma colonies/mycelia and hyphal tip culture of the Trichoderma isolates was done on PDA plates to obtain their pure cultures. Altogether, ten Trichoderma isolates (T. harzianum and T. viride) were successfully isolated from 10 soil samples, the details of which are presented in Table 1.

Table 1. Details of place of collection and the host plant for Trichoderma isolation

\begin{tabular}{|c|c|c|c|c|}
\hline $\begin{array}{l}\text { Trichoderma } \\
\text { isolate }\end{array}$ & Host plant & Place of soil collection & $\begin{array}{l}\text { GPS coordinates of the } \\
\text { location }\end{array}$ & Elevation \\
\hline $\mathrm{T} 153$ & Eggplant & Bhokrah, Sunsari & $26.6140^{\circ} \mathrm{N}, 87.0924^{\circ} \mathrm{E}$ & 352 masl \\
\hline $\mathrm{T} 154$ & Avocado & Bandipur, Tanahun & $27.9170^{\circ} \mathrm{N}, 84.4068^{\circ} \mathrm{E}$ & 1030 masl \\
\hline T282 & Rice & Naikap, Kathmandu & $27.4227^{\circ} \mathrm{N}, 85.1805^{\circ} \mathrm{E}$ & 1300 masl \\
\hline T283 & Rice & Manthali-1, Ramechhap & $27.2318^{\circ} \mathrm{N}, 86.3473^{\circ} \mathrm{E}$ & 1533 masl \\
\hline T285 & Chilli & Nala & $27.6171^{\circ} \mathrm{N}, 85.5504^{\circ} \mathrm{E}$ & 984 masl \\
\hline T338 & Sugarcane & Jitpur, Bara & $27.1042^{\circ} \mathrm{N}, 84.4316^{\circ} \mathrm{E}$ & 111 masl \\
\hline T354 & Garlic & Dang & $27.9903^{\circ} \mathrm{N}, 82.3017^{\circ} \mathrm{E}$ & 603 masl \\
\hline T357 & Soybean & Dakshinkali, Kathmandu & $27.4227^{\circ} \mathrm{N}, 85.1805^{\circ} \mathrm{E}$ & 1292 masl \\
\hline T362 & $\begin{array}{l}\text { Broad leaf } \\
\text { musard }\end{array}$ & Dhading besi, Dhading & $27.9110^{\circ} \mathrm{N}, 84.8919^{\circ} \mathrm{E}$ & 609 masl \\
\hline T363 & Ginger & Kapurkot, Salyan & $28.2231^{\circ} \mathrm{N}, 82.9423^{\circ} \mathrm{E}$ & 1530 masl \\
\hline
\end{tabular}

\section{Culture of Plant Pathogens}

Three soil borne plant pathogens viz; Fusarium solani, Rhizoctonia solani and Sclerotinia sclerotiorum were isolated from diseased roots of tomato, broad leaf mustard and cauliflower respectively. For isolation of the pathogens diseased samples were cut into $1 \mathrm{~cm}$ pieces and surface sterilized in $1 \%$ sodium hypochlorite solution for 1 minute followed by rinsing with distilled water thrice. Samples were placed on blotting paper and dried inside laminar flow. Then they were transferred to water agar plates and incubated at $25^{\circ} \mathrm{C}$. The growth of the pathogen was observed on second day of plating and the mycelia were transferred to PDA plates for pure culture of pathogens. 


\section{Dual Culture of Trichoderma and Pathogens}

The experiment was performed in November 2018 in the laboratory of Plant Pathology Division, Lalitpur. One week old cultures of Trichoderma isolates and plant pathogens were used for the study. Five millimeter disc of above mentioned soil borne pathogens and bio-control agents were placed apart on solidified PDA medium in an equal distance and incubated. Three plates for each treatment for each pathogen were used as three replicates and the experiment was set in completely randomized design (CRD). The plates inoculated with pathogens without Trichoderma isolates served as control. Radial colony growth of Trichoderma and pathogens was measured every day for a week. Percent inhibition of the pathogen growth was calculated by using the formula developed by Vincent 1947.

$$
\mathrm{I}(\%)=\frac{\mathrm{C}-\mathrm{T}}{\mathrm{C}} \times 100
$$

where, $\mathrm{C}=$ radial growth in control plate (without Trichoderma)

$\mathrm{T}=$ radial growth in Trichoderma inoculated plate

\section{Statistical Analysis}

MSTATC was used for the analysis of variance (ANOVA) to test the significance of treatment effect on colony growth of different pathogens. Duncan's multiple range test (DMRT) was used to compare the values of significant treatment means at $1 \%$ level of significance.

\section{RESULTS}

All of the Trichoderma isolates exhibited significant inhibition of the three pathogens as compared to control. However, the tested Trichoderma isolates differed in their abilities to suppress various pathogens. T363 isolate was found as best for inhibition of S. sclerotiorum (87.81\%), while T357 proved to be most effective for F. solani control (84.76\%). As for $R$. solani, six of the tested isolates (T153, T283, T285, T357, T362, and T363) exhibited more than $80 \%$ reduction in growth (Table 2). Some Trichoderma isolates were found to overgrow the pathogens completely after a week of inoculation.

Table 2. Effect of Trichoderma isolates on radial colony growth of soil borne plant pathogens

\begin{tabular}{|c|c|c|c|c|c|c|}
\hline \multirow{2}{*}{$\begin{array}{l}\text { Treatment } \\
\text { (Trichoderma } \\
\text { isolates) }\end{array}$} & \multicolumn{2}{|c|}{ S. sclerotiorum } & \multicolumn{2}{|c|}{ F. solani } & \multicolumn{2}{|c|}{ R. solani } \\
\hline & $\begin{array}{l}\text { Radial colony } \\
\text { growth }(\mathbf{c m})\end{array}$ & $\begin{array}{l}\text { Inhibition } \\
\%\end{array}$ & $\begin{array}{l}\text { Radial colony } \\
\text { growth }(\mathbf{c m})\end{array}$ & $\begin{array}{l}\text { Inhibition } \\
\%\end{array}$ & $\begin{array}{l}\text { Radial colony } \\
\text { growth }(\mathbf{c m})\end{array}$ & $\begin{array}{l}\text { Inhibition } \\
\%\end{array}$ \\
\hline $\mathrm{T} 153$ & $4.05(2.01) b c$ & 42.1 & $5.31(2.30) \mathrm{a}$ & 24.19 & $1.29(1.13) \mathrm{d}$ & 81.55 \\
\hline T154 & $2.85(1.68) \mathrm{f}$ & 59.24 & $2.27(1.50) \mathrm{b}$ & 67.62 & $1.42(1.19) \mathrm{d}$ & 79.76 \\
\hline $\mathrm{T} 282$ & $4.37(2.09) \mathrm{b}$ & 37.52 & $2.96(1.72) \mathrm{b}$ & 57.71 & $3.71(1.92) \mathrm{c}$ & 47.02 \\
\hline T283 & 3.92 (1.97)bcd & 44.00 & $2.16(1.46) \mathrm{b}$ & 69.14 & $1.33(1.15) \mathrm{d}$ & 80.95 \\
\hline $\mathrm{T} 285$ & $3.15(1.77) \mathrm{ef}$ & 55.05 & $1.87(1.36) b c$ & 73.33 & $1.38(1.17) \mathrm{d}$ & 80.36 \\
\hline $\mathrm{T} 338$ & $3.60(1.89) \mathrm{cde}$ & 48.57 & $2.40(1.54) \mathrm{b}$ & 65.71 & $4.25(2.06) \mathrm{b}$ & 39.29 \\
\hline T354 & $2.93(1.71) \mathrm{f}$ & 58.1 & $1.89(1.37) b c$ & 72.95 & $1.50(1.22) \mathrm{d}$ & 78.57 \\
\hline T357 & 3.87 (1.96)bcd & 44.76 & $1.07(1.03) \mathrm{c}$ & 84.76 & $1.29(1.13) \mathrm{d}$ & 81.55 \\
\hline $\mathrm{T} 362$ & $3.36(1.83) \mathrm{def}$ & 52.00 & $1.84(1.35) b c$ & 73.71 & $1.29(1.13) \mathrm{d}$ & 81.55 \\
\hline T363 & $0.85(0.92) \mathrm{g}$ & 87.81 & $2.00(1.41) b c$ & 71.43 & $1.38(1.17) \mathrm{d}$ & 80.36 \\
\hline Control & $7.00(2.64) \mathrm{a}$ & 0.00 & $7.00(2.64) \mathrm{a}$ & 0.00 & $7.00(2.64) \mathrm{a}$ & 0.00 \\
\hline LSD & $0.02(0.15)$ & & $0.11(0.34)$ & & $0.006(0.07)$ & \\
\hline P-value & $* * *$ & & $* * *$ & & $* * *$ & \\
\hline $\mathrm{CV} \%$ & 4.58 & & 11.54 & & 3.43 & \\
\hline
\end{tabular}

Values are means of three replicates. For radial colony growth, figures in parenthesis represent square root transformed values. Means followed by the same letter in a column are not significantly different (DMRT, $P=0.01$ ).

\section{DISCUSSION}

Variation in the antagonistic activity by Trichoderma species has been explained by several authors (Bell et al 1982, Gveroska 2013, Hima and Beena 2016, Thavaselvi et al 2016). The intensive development of 
Trichoderma gives it a significant advantage in competition with pathogens for nutrients and space, besides the production of mycotoxins (Howell 2003). The mechanism of Trichoderma to control pathogens may be by attacking and binding the pathogenic organisms by sugar linkage and begins to secrete extracellular protease and lipase (Agrawal and Kotasthane 2012). Trichoderma sp grown over the pathogenic fungal hyphae coils around them and degrades the cell walls (Reddy et al 2014). This action of parasitism restricts the development and activity of pathogenic fungi (Asad et al 2014).

Reduced sclerotia formation of $S$. sclerotiorum and $R$. solani in dual culture with Trichoderma isolates has been observed by previous authors. Abdulla et al 2008 observed that local T. harzianum isolate reduced sclerotia formation of S. sclerotiorum. Seema and Devaki 2012 also found decreased sclerotia formation of $R$. solani by Trichoderma species in an in vitro assay. Sclerotia are the resistant structures of the aforementioned pathogens which serve as means of survival during unfavourable conditions. Hence reduction of sclerotia formation can have a significant effect on minimizing inoculum levels in fields (Agrios 2005). Ommati and Zaker 2012 reported biocontrol effect of Trichoderma longibrachiatum and $T$. brevicompactum against Fusarium solani in pot culture. Timila and Manandhar 2016 also found local Trichoderma harzianum isolate to control Phytophthora blight of pepper in field conditions. Similarly, efficacy of various Trichoderma species against different pathogens has been well documented (Ha 2010).

Various Trichoderma species have different ecological adaptability and hence it is wise to test native Trichoderma isolates for biocontrol of pathogens and exploit them in commercial formulations rather than to import biopesticides from other countries (Elad et al 1980). There are many evidences of Trichoderma being excellent antagonists against pathogens in laboratory and greenhouse conditions while they cannot perform well in fields (Glare et al 2012). In many cases, the exotic isolates cannot adapt to the new soil and ecology and hence cannot colonise soils. Therefore it is important to test the native isolates and try them in similar ecological niches. An in vitro screening facilitates for selection of effective isolates and hence eliminates the need to test a large number of Trichoderma isolates which would otherwise require a lot of space and time for field experimentations and applications both. The effective isolates identified from the present study can be used for further trial in pots or fields.

\section{CONCLUSION}

The tested Trichoderma isolates (T. harzianum and T. viride) showed varying degrees of antagonism against the soil borne plant pathogens. This reveals the pathogen specificity of the Trichoderma isolates. The effective isolates concluded from the study should be tested for their efficacy in in vivo conditions. A close linkage between research and biopesticide companies is necessary so as to use the identified potential biocontrol agents in commercial formulations.

\section{ACKNOWLEDGEMENTS}

We would like to acknowledge Nepal Agricultural Research Council (NARC) for provision of the fund to conduct this experiment. We are grateful to former senior scientist of NARC, Dr Ram Devi Timila for her technical guidelines to conduct the trial. Mr. Ajaya Karkee, scientist is also cordially thanked for helping with statistical analysis of the data.

\section{REFERENCES}

Abdulla MT, NY Ali and P Suleman. 2008. Biological control of Sclerotinia sclerotiorum (Lib.) de Bary with Trichoderma harzianum and Bacillus amyloliquefaciens. J. Crop Prot. 27(10): 1354-1359.

Agrawal T and AS Kotasthane. 2012. Chitinolytic assay of indigenous Trichoderma isolates collected from different geographical locations of Chhattisgarh in Central India. SpringerPlus 1:73

Agrios GN. 2005. Plant Pathology $5^{\text {th }}$ edition. In: Root and Stem Rots caused by Basidiomycetes. Elsevier Academic Press USA; pp. 593-599. 
Asad SA, N Ali, A Hameed, SA Khan, R Ahmad, M Bilal, M Shahzad and A Tabassum. 2014. Biocontrol efficacy of different isolates of Trichoderma against soil borne pathogen Rhizoctonia solani. Polish J. Microbiol. 63(1): 95-103.

Bell DK, HD Wells and CR Markham. 1982. In vitro antagonism of Trichoderma species against six fungal plant pathogens. J. Phytopathol. 72: 279-382.

Benitez T, AM Rincon, MC Limon and AC Codon. 2004. Biocontrol mechanisms of Trichoderma strains. Int. J. Microbiol. 7: 249-260.

Elad Y, I Chet and J Katan. 1980. Trichoderma harzianum: A biocontrol agent effective against Sclerotium rolfsii and Rhizoctonia solani. J. Phytopathol. 70(2): 119-121.

Glare T, J Caradus, W Gelernter, T Jackson, N Keyhani, J Kohl, P Marrone, L Morin and A Stewart. 2012. Review. Have biopesticides come of age? J. Trends Biotechnol. 30: 9-11.

Gveroska B. 2013. In vitro biocontrol activity of Trichoderma harzianum against some pathogenic fungi on tobacco. J. Food and Environ. safety 12(1): 95-104.

Ha TN. 2010. Using Trichoderma species for biological control of plant pathogens in Vietnam. J. ISSAAS. 16(1): 17-21.

Hima VM and S Beena. 2016. In vitro antagonism of Trichoderma spp against six soil borne fungal pathogens. Int. J. Appl. Pure. Sci. 2(3): 45-48.

Howell CR. 2003. Mechanisms employed by Trichoderma species in the biological control of plant diseases: History and Evolution of current concepts. J. Plant Dis. 87(1): 4-10.

Junaid J, MNA Dar, TA Bhat, AH Bhat and MA Bhat. 2013. Commercial biocontrol agents and mechanism of action in the management of plant pathogens. J. Mod. Plant. Anim. Sci. 1(2): 39-57.

Kamala T and SI Devi. 2012. Biocontol properties of indigenous Trichoderma isolates from North-east India against Fusarium oxysporum and Rhizoctonia solani. Afr. J.Biotechnol. 11(34): 8491-8499.

Kumar G, A Maharshi, J Patel, A Mukherjee, HB Singh and BK Sharma. 2017. Trichoderma: A potential fungal antagonist to control plant diseases. SATSA Mukhapatra- Annual Technical Issue 21: 206-218.

Motlagh MRS and Z Samimi. 2013. Evaluation of Trichoderma spp, as biological agents in some of plant pathogens. Ann. Biol. Res. 4(3): 173-179.

Mukherjee M, PK Mukherjee, BA Horwitz, C Zachow, G Berg and S Zeilinger. 2012. Trichoderma- Plant-Pathogen interactions: Advances in genetics of biological control. Indian J. Microbiol. 52(4): 522-529.

Ommati F and M Zaker. 2012. In vitro and greenhouse evaluations of Trichoderma isolates for biological control of potato wilt disease (Fusarium solani). Arch. Phytopathol. Plant Prot. 45(14): 1715-1723.

Pandya JR, AN Sabalpara and SK Chawda. 2011. Trichoderma: A particular weapon for biological control of Phytopathogens. J. Agri. Tech. 7(5): 1187-1191.

Ramzan N, N Noreen and S Shahzad. 2014. Inhibition of in vitro growth of soil borne pathogens by compostinhabiting indigenous bacteria and fungi. Pakistan J. Bot. 46(3): 1093-1099.

Reddy BN, KV Saritha and A Hindumathi. 2014. In vitro screening for antagonistic potential of seven species of Trichoderma against different plant pathogenic fungi. Res. J. Biol. 2: 29-36.

Seema M and NS Devaki. 2012. In vitro evaluation of biological control agents against Rhizoctonia solani. J. Agri.Tech. 8(1): 233-240.

Thavaselvi A, K Kanimozhi, A Panneerselvam and RS Soundra. 2016. In vitro screening of Trichoderma spp against collar rot pathogen. Int. J.Curr. Res. 8(6): 32323-32326.

Timila RD and S Manandhar. 2016. Biocontrol Efficacy of Trichoderma spp Against Phytophthora Blight of Pepper (Abstract). In: Proc. First International Horticulture Conference, 8-11 April,Kathmandu: NARC; pp. 277.

Vincent JM. 1947. Distortion of fungal hyphae in the presence of certain inhibitors. Nature 159 (4051): 850.

Weindling R. 1934. Studies on a lethal principle effective in the parasitic action of Trichoderma lingorum on Rhizoctonia solani and other soil fungi. J. Phytopathol. 24: 1153-1159.

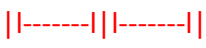

